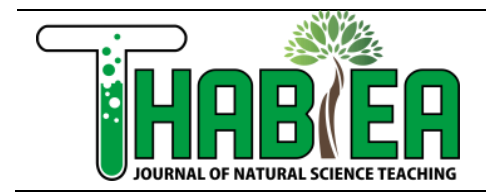

Thabiea : Journal of Natural Science Teaching

Vol. 4(2), pp. 148-158, 2021

Available online at

http://journal.iainkudus.ac.id/index.php/Thabiea

p-issn: 2580-8474, e-issn: 2655-898X

\title{
Student Sustainability Disposition: Where Are Students' Levels?
}

\author{
Nanda Syah Putra ${ }^{1 *}$, Anna Permanasari², Desi Desmiawati ${ }^{3}$ \\ Universitas Pendidikan Indonesia, Setiabudhi Street. 229 ${ }^{\text {th }}$, Isola, Bandung, 40154, Indonesia \\ *Correspondence: nandamursamad@upi.edu
}

\author{
Keywords: \\ ESD, \\ Sustainable living, \\ Appropriate learning, \\ ESD themes, \\ Sustainability disposition
}

\begin{abstract}
Education for sustainability development (ESD) is a way to realize that every individual lives interdependently with each other and their environment. Research has been conducted with survey methods to reveal the level of students' disposition/attitude to sustainable living, being a basis for the development of appropriate learning. The research sample was 95 students at SMPN Garut. The data in this study is primary data, which is obtained directly from the research subject. The research was conducted by delivering questionnaires to students consisting of 51 closed question items. The results of the study obtained the average of student disposition score from several ESD themes, namely the environment, waste, water, energy, natural disasters, and health respectively is $2.99,3.15,3.24,3.11,3.08$ and 3.33. The average of these all themes is 3.15. Based on this study, the results were obtained that students' sustainability disposition/attitude are at a high level. The positive response given by students shows the attitude of students who support the efforts to realize sustainable development. In this case, there is no guarantee if someone who have good sustainability disposition will have good sustainability practice. Sustainable disposition/attitude must be supported by sustainable behaviors and practices so that sustainable living goals can be achieved. The last, Indonesia government can make the policy and guidelines related to how to do effective sustainability education in Indonesia to support sustainability awareness of students and society.
\end{abstract}

To cite this article:

Putra, N. S., Permanasari, A., Desmiawati, D. (2021). Student Sustainability Disposition: Where Are Students' Levels?. Thabiea : Journal of Natural Science Teaching, 4(2), 148-158.

\section{Introduction}

Nowadays, various global problems (e.g hunger, poverty, inequality, access to proper education, health, welfare, sanitation, climate change) greatly affect the balance of human life ( Buralli et al., 2018). Then, real environmental problems in our life such as illegal logging, forest land clearing (Indrati \& Hariadi, 2016), climate change, water quality, hazardous and toxic waste, ecosystem quality, biodiversity loss (OECD, 2008) need to be urgently found the solution. The problems were mostly caused by human activities. In Indonesia, development activities sometime ignore environmental sustainability. So that, expectation to promote life quality by doing development in this country turns out to have any risk in human life.(Rosana, 2018). Broken nature can't provide a proper place to live and natural resource support as well as unequal social order is a source of dissatisfaction and social disaster (Abdoellah, 2016) All these problems need to be solved for the sustainability of human life in the future. 
In 2015, the United Nations declared the Sustainable Development Goals (SDGs) (Pedersen, 2018) and the agenda 2030 for sustainable development. SDGs aims to create a sustainable life by ending the poverty, discussing about hunger, health, education, gender equality, water and sanitation, energy (Mensah, 2019) and ensuring everyone enjoys a peaceful life in the present and future (Morton et al., 2017). So, SDGs aims for making sure sustainable development in social, economic, environmental issues (Jones et al., 2017) as well as creating peace (García-Feijoo et al., 2020). Various problems that appear in environmental and social dimensions relate to human activities in economy dimension in producing goods and service (Cahyadinto, 2010).

Sustainable development is one of the biggest challenges faced by people in this age where the demands of creating a sustainable environment and balancing social and economic life at the same time (Berglund et al., 2020). Education is the best way to introduce and to provide an understanding of sustainable development to the community. The form of education that affects specifically and greatly in sustainable development is Education for Sustainable Development (ESD) (Tristananda, 2018). Education is the best way to foster the values of sustainable development of society by changing the mindset of learners. Then, it is expected that students can apply the values to maintain a sustainable life in the future.

Education for Sustainable Development aims to address massive global problems (Dube \& Lubben, 2011) as discussed in the SDGs objectives. Science education for sustainable development represents a discussion for a very broad topic of social, economic, and environmental development by expecting output on changes in the attitudes of learners to support sustainable development activities (Seely et al., 2014). In other words, ESD programs support students to have future-oriented thinking skill. The ability of future-oriented thinking can be defined as meta-competency, which includes complex thinking, conducting discussions with experts and stakeholders, solving inaccuracies, making choices and making changes (Julien et al., 2018). So in practice, ESD not only affects the contents and themes of learning but also will change the culture of education in the process and the results (Gatti et al., 2019).

All educational stakeholders have a very important role for successing sustainable education. Wardani (2020) stated that effective implementation of environmental education (adiwiyata program) in Indonesia should be supported by stakeholders. So, ESD is expected to be implemented in all schools in Indonesia, through science subjects. Then, among of all stakeholders, teachers have an important role in the progress of classroom learning (Sumiati, 2018). Underqualified teacher and rote learning are some of problems on implementation of environmental education (Parker \& Prabawa-sear, 2019). Therefore, teacher competency is one of the key factor to success scientific learning (Afandi, 2015)

The development of implementation environmental education in Indonesia began in 1975 and was pioneered by IKIP Jakarta (Surakusumah, 2009). The delivery of population and environmental problems was outlined in 1984 Curriculum and incorporated to almost of all subjects (Sudjoko, 2014). So that, the learning process that is in common with the concept of ESD has been implemented at various levels of education in Indonesia long before the term ESD was introduced in Indonesia. Mochtar et al. (2014) stated that 2013 curriculum is actually the embodiment of ESD. In Indonesia, curriculum 2013 encourages the achievement of a balance between attitude and knowledge and skill of learners (Gusviani, 2016). The principles 
developed in curriculum 2013 are basically efforts to empower and enable each individual to participate in society.

The integration of ESD themes into science curriculum taught in schools is needed to achieve education for sustainable development goals. The problems related to ESD themes should be discussed in learning proccess with students constructing their own knowledge. By integration of ESD themes on learning process, it is expected that students will promote their sensitivity to sustainable development problems. Therefore, the research was to reveal students' sustainability disposition on several themes of sustainable development that can be integrated in science learning.

\section{Method}

This research is a survey research conducted in a Junior High School in Garut. The school is located in green open space. Then, Junior high school is taught integrated physics, chemistry and biology matter in science subjects. Some of sustainable development themes are discussed specifically in science education of junior high school. So that, need to know the sustainability disposition of students on several themes that can be integrated in science learning. The number of respondents in this study is 96 students consisting of grade VII, VIII, and IX students. Table 1 shows number of respondents in each class

\begin{tabular}{ll}
\multicolumn{2}{c}{ Table 1. Number of respondent } \\
\hline Grade & Respondent \\
\hline VII & 28 \\
VIII & 30 \\
IX & 38
\end{tabular}

There are numerous themes of sustainability included health, biodiversity, resource conservation, disaster risk reduction, etc. (UNESCO, 2012). ESD means to solve the problems threatening our future such as wasteful comsumption, health (included HIV/AIDS), nutrition, environmental degradation, global warming, etc. (Combes, 2005). The research was conducted by delivering questionnaires to students consisting of 51 closed question items. The question item consists of 6 themes about sustainable development. In this study, the choosen several themes of sustainable development is that can be integrated in science learning. The number of items was the considering to the relevant issue in Indonesia related to the choosen themes. The reliability of instruments was analysed by using SPSS program. The reliability value of instrument used in this study is 0.874 and is categorized high. Table 2 shows the number of question items per sustainable development themes. 
Table 2. Number of Questions

\begin{tabular}{ll}
\hline Theme & Questions \\
\hline - Environment & 12 item \\
- Waste & 4 item \\
- Water & 6 item \\
- Energy & 4 item \\
- Disaster & 10 item \\
- Health & 15 item
\end{tabular}

Some of these themes consist of some sub-themes namely environmental theme consisting of 3 sub-themes, disaster theme consisting of 2 sub-themes, health theme consisting of 3 sub-themes. The detail information of sub-themes is available on result and discussion chapter. Questions are type of questionnaire likert scale. Responses of students are processed and presented in tables. The use of likert scale according to Sugiyono (2011) is a data collection technique that asks respondents to answer some statements or questions as a source of information. Calculation of scores is based on the calculation of average (Weight Means Score). To categorize the tendency of respondents' answers is according to the following table:

Table 3. Score Interpretation of students' answer tendency

\begin{tabular}{ll}
\hline Criteria & Interval \\
\hline Strongly Agree & $3,25-4$ \\
Agree & $2.5-3,24$ \\
Disagree & $1,75-2.49$ \\
Strongly Disagree & $1-1.74$
\end{tabular}

Then, to categorize students' level of sustainability disposition is according to the following table:

Table 4. Interpretation of average score of student's sustainability disposition

\begin{tabular}{ll}
\hline Criteria & Interval \\
\hline Low & $1.0-2.0$ \\
Medium & $2.01-3.0$ \\
High & $3.01-4.0$
\end{tabular}

\section{Results and Discussion}

In the first part of the questionnaire, students were asked about their opinions on the environment. For environmental theme the question is divided into several sub-themes. And then the sub-themes consist of several question items that explore the opinions of students. Table 4 shows sub-themes that discuss the environment and the number of question items contained in the sub-theme. 
Table 4. Number of items for environmental theme

\begin{tabular}{clc}
\hline NO & \multicolumn{1}{c}{ Sub-theme } & Questions \\
\hline 1 & $\begin{array}{l}\text { Related to Prevention of } \\
\text { environmental damage }\end{array}$ & 3 items \\
2 & $\begin{array}{l}\text { Related to Tackling the impact of } \\
\text { environmental damage }\end{array}$ & 5 items \\
3 & $\begin{array}{l}\text { Related to Environmental } \\
\text { sustainability maintenance }\end{array}$ & 4 items
\end{tabular}

Sub-theme 1 related to environmental damage prevention, we observed that the average of student answer is 2.72 , for the average for sub-theme 2 related to environmental damage impact management is 2.97, and for the average of sub-theme 3 related to environmental sustainability maintenance is 3.29. For more details can be seen in figure 1 .

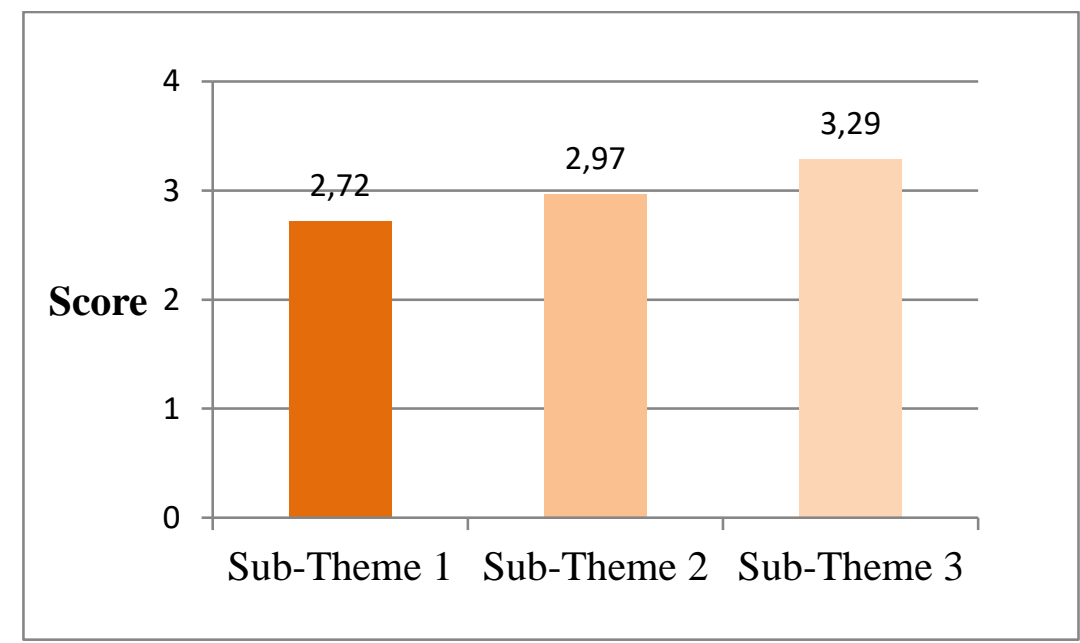

Figure 1. Score of student sustainability disposition on environmental theme

The average score of student answers from all three sub-themes was 2.99 in the "agree" category. The response given by the student to the question shows that students support the efforts made in solving environmental problems. In other words, learning in schools provided by teachers already leads to the desired values in the materials contained in the ESD, especially environmental issues. However, in some answered items, it is found that the average score on the item is mostly negative response with the category of "disagree". Based on interview result on sample of students, it was found that specifically for such item students are not familiar with the question. This is caused by teachers never or rarely offend about it in learning proccess.

The next part of the questionnaire is respectively about water, waste and energy. Questions about each theme explore students' opinions about the issues related to the theme of water, waste and energy. Students' opinion score for waste theme is 3.15; for water theme is 3.24; and for energy theme is 3.11. Table 5 shows the number of questions for theme and figure 2 shows the average score of students' opinions. 
Table 5. Number of question items about water, energy, and waste themes

\begin{tabular}{ccc}
\hline NO & Theme & Questions \\
\hline 1 & Waste & 4 items \\
2 & Water & 6 items \\
3 & Energy & 4 items
\end{tabular}

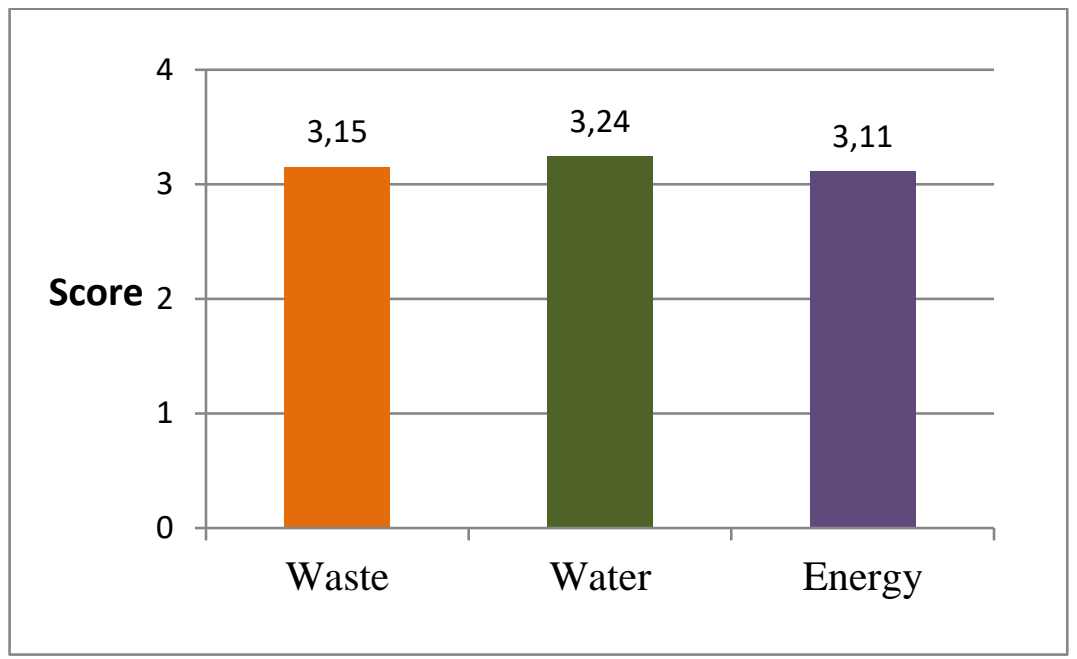

Figure 2. Score of student sustainability disposition on waste, water and energy theme

Based on figure 2 the interpretation of score is "agree". From the result, we can conclude that students have a positive attitude in facing sustainable development. These results also illustrate that the process of implementing learning in the classroom has led to sustainability education themes. The student's response describes the character of the student which is the result of teaching and learning activities conducted in the school.

Then, the questionnaire section asked students about their opinion about the theme of the disaster. This theme consists of two sub-themes, namely related to Natural Disaster Mitigation, and related to Disaster Management. Students were asked their opinions about the related issues and problems in each sub-theme. Table 6 shows the number of question items about disaster themes and figure 3 shows the average score of students' opinions.

Table 6. Number of question items about disaster theme

\begin{tabular}{rlr}
\hline NO & \multicolumn{1}{c}{ Sub-Theme } & \multicolumn{1}{c}{ Questions } \\
\hline 1 & $\begin{array}{l}\text { Related to Natural Disaster } \\
\text { Mitigation }\end{array}$ & 6 item \\
2 & $\begin{array}{l}\text { Related to Disaster } \\
\text { Management }\end{array}$ & 4 item \\
\hline
\end{tabular}




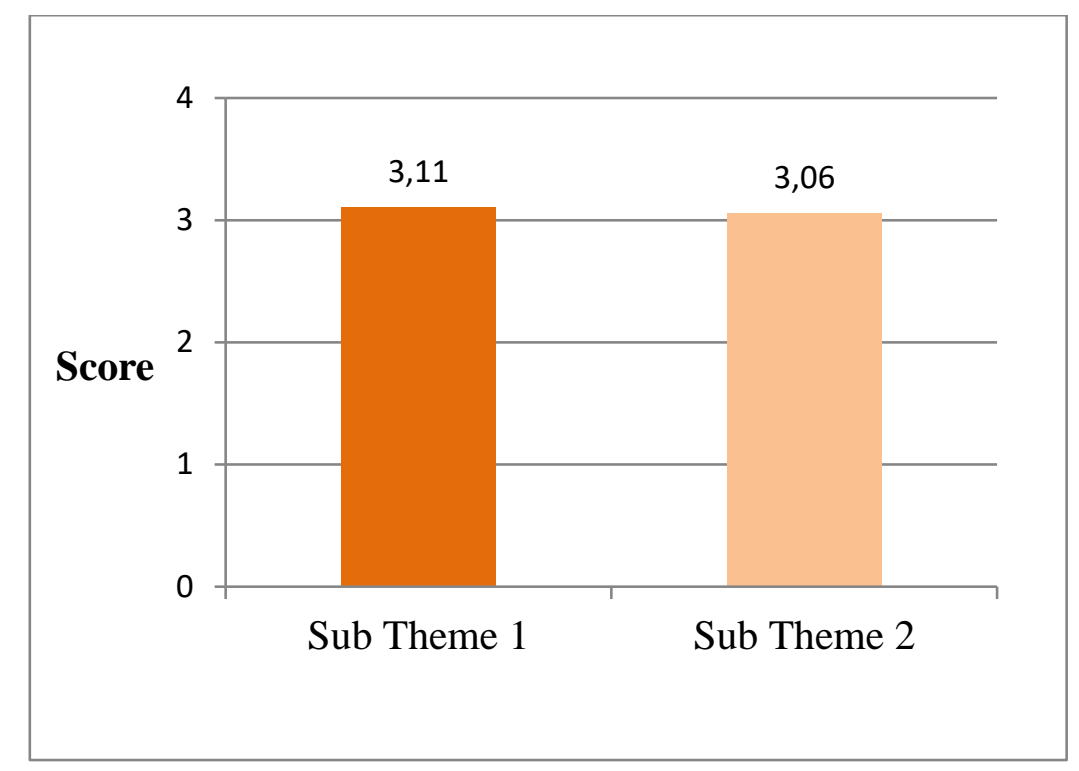

Figure 3. Score of student sustainability disposition on disaster theme

Table 6 shows interpretation of each sub-theme of disaster is "agree", with an average score 3.11 and 3.06. So the average of the two sub-themes is 3.08 and interpretated "agree". The results obtained show the implementation of learning in the classroom has been directed in sustainability education themes. The positive response given by the students shows that the sustainable disposition is at a fairly high level.

The last part of this questionnaire is about the health theme. This section consists of 3 sub-themes, namely related to health care, related to the prevention of infectious diseases of HIV / AIDS and related to the prevention of infectious diseases Covid-19. Table 7 shows the number of question items on health theme and figure 4 shows the average score of students' opinions.

Table 7. Number of question items about health theme

\begin{tabular}{cll}
\hline NO & \multicolumn{1}{c}{ Sub-Theme } & Questions \\
\hline 1 & $\begin{array}{l}\text { Related to health care } \\
\text { Related to the prevention of } \\
\text { infectious diseases of HIV / } \\
\text { AIDS }\end{array}$ & $\begin{array}{l}6 \text { items } \\
\text { Related to the prevention of } \\
\text { infectious diseases Covid-19 }\end{array}$ \\
\hline
\end{tabular}




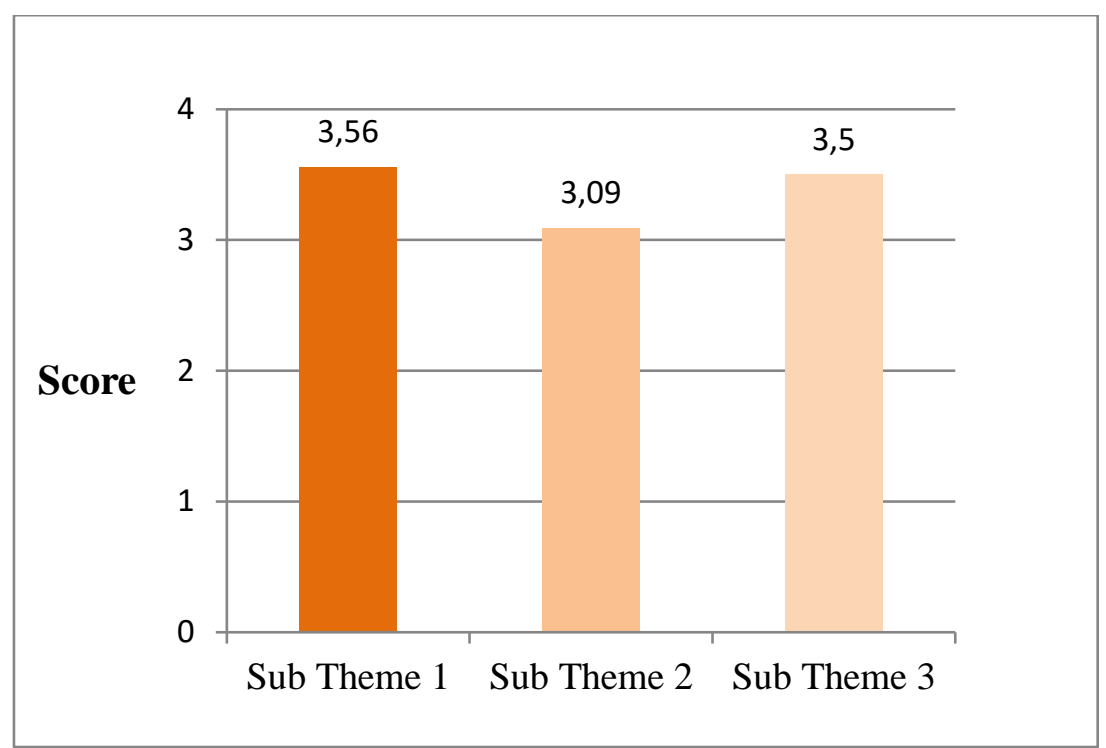

Figure 4. Score of student sustainability disposition on health theme

The interpretation of the student's opinion score on the health theme is "strongly agree" with the average 3.33. This acquisition is different from other previous themes where the average student's opinion on the previous theme is categorized as "agree". The "agree" response given by students shows that students are very aware of the importance of health. "Strongly agree", it means students strongly support efforts for sustainable living especially on health theme.

In general, the average of students' sustainable disposition result is 3.16 and is categorized as being at a fairly high level. This positive response shows that learners have a positive disposition in supporting sustainable development. Sometime, a good sustainability disposition could figure out a good sustainability practice, but there is no guarantee if someone who have good sustainability disposition will have good sustainability practice. This statement is in line with research conducted by Clarisa et.al (2020) that among three categories of sustainability awareness, sustainability practice is the lowest one. Related to this, the Directorate General of Basic Education has also drawn up guidelines for sustainable development education with one of the objectives is to provide information about the integration of ESD materials in the curriculum. Then, the implementation of the 2013 curriculum in Indonesia has adopted the principles of education for sustainable development. The real application on curriculum is the emphasis on changing the character of students after the learning process. In addition, the emphasis on the application of scientific approaches in learning supports students to have critical thinking ability in problem solving which is important ability to carry out sustainable development.

Then, the learning activities conducted by teachers in the classroom will greatly affect the skills of science by students. In case, to promote individual and community environmental literacy, teachers play an important role (Tosun \& Gursakal, 2016). Teachers should apply the learning process with student-centered principles. It is no longer a teacher-centered where teachers become the center of attention and present all the needs of student materials. Students should get used to building their own concepts by solving their problem or issue related to learning topic. So that, students are sensitive to daily problems and used to find solutions. In 
addition, it is necessary to commit all school communities in applying ESD values in schools so as to be an example for students (Listiawati, 2013).

The government shows seriousness in promoting sustainable development by issuing Law No. 59 of 2017 on the Implementation of Sustainable Development. The government also established a National Secretariat of SDGs that has the role to coordinate the activities of SDGs and to ensure good implementation in Indonesia (Sudagung et al., 2019). The campus also plays a very important role in raising sustainable awareness Campus efforts in raising sustainable awareness are by implementing sustainable development policies. In Indonesia, most campuses adopt the concept of green campus as the main concept to realize sustainable development (Fatmawati \& Syahbana, 2015). Then, the campus is the institution where various research products are produced. The role of research results related to sustainable fields can develop various ways to overcome various problems in sustainable living (Permatasari, 2016).

Furthermore, in addition to sustainable attitudes, students must also have sustainable behaviour and practice. Sustainable attitudes must be supported by sustainable behaviors and practices, so that sustainable living goals can be achieved. To instill sustainable values towards students who have good sustainable attitudes, behaviors and practices, a figure of a literate teacher towards sustainable living is required. Therefore, it is necessary to implement policies in the campus by implementing education for sustainable development, especially for prospective educators / teachers.

\section{Conclusion}

Education has a main role to prepare the future society that supports sustainable development. This research is a survey research conducted at a Junior High School in Garut to reveal students' sustainability disposition on several themes of sustainable development that can be integrated in science learning. There are 6 themes discussed in this research namely environment, waste, water, energy, health and disaster. The average of students' sustainable disposition result of all themes is 3.16 and is categorized as being at a fairly high level. This positive response shows that students have a positive attitude in supporting sustainable development programs. Then, there is no guarantee if someone who have good sustainability disposition will have good sustainability practice. In addition to sustainable attitudes, one of the most important things is students must also have sustainable behavior. Sustainable disposition/attitude must be supported by sustainable behaviors and practices so that sustainable living goals can be achieved. So, by knowing the importance of having good sustainability attitude, behaviour, and practice, there is an urgency for teacher and all stakeholder to implement the sustainability education that accommodate all of these. To instill sustainable values towards students need a figure of a sustainable literate teacher. So that, it is necessary to implement policies in the campus by implementing education for sustainable development, especially for prospective educators / teachers. The last, Indonesia government can make the policy and guidelines related to how to do effective sustainability education in Indonesia to support sustainability awareness of students. 


\section{Acknowledgment}

The writer would like to deliver the greatest gratitude to the Indonesian Endowment Fund of Education (LPDP) for the financial support.

\section{References}

Abdoellah, O. S. (2016). Pembangunan berkelanjutan di Indonesia: Di persimpangan jalan. Jakarta: Gramedia Pustaka Utama.

Afandi, M. (2015). Kompetensi Guru Sebagai Kunci Keberhasilan Dalam Pembelajaran Saintifik. Seminar Nasional Pendidikan, 74-88.

Berglund, T., Gericke, N., Boeve-de Pauw, J., Olsson, D., \& Chang, T. C. (2020). A crosscultural comparative study of sustainability consciousness between students in Taiwan and Sweden. Environment, Development and Sustainability, 22, 6287-6313.

Buralli, R. J., Canelas, T., Carvalho, L. M., Duim, E., Itagyba, R. F., Fonseca, M., Oliver, S. L., \& Clemente, N. S. (2018). Moving towards the Sustainable Development Goals: The UNLEASH Innovation Lab experience. Ambiente e Sociedade, 21.

Cahyandito, M. F. (2010). Pembangunan Berkelanjutan, Ekonomi dan Ekologi, Sustainability Communication dan Sustainability Reporting. Jurnal Bisnis dan Manajemen, 5(1).

Combes, B. P. (2005). The United Nations decade of education for sustainable development (2005-2014): Learning to live together sustainably. Applied Environmental Education and Communication, 4(3), 215-219.

Clarisa, G., Danawan, A., Muslim, M., \& Wijaya, A. F. C. (2020). Penerapan Flipped Classroom dalam Konteks ESD untuk Meningkatkan Kemampuan Kognitif dan Membangun Sustainability Awareness Siswa. Journal of Natural Science and Integration, 3(1), 13-25.

Dube, T., \& Lubben, F. (2011). Swazi teachers' views on the use of cultural knowledge for integrating education for sustainable development into science teaching. African Journal of Research in Mathematics, Science and Technology Education, 15(3), 68-83.

Fatmawati, S., \& Syahbana, J. A. (2015). Penerapan Kebijakan Pembangunan Berkelanjutan di Lingkungan Kampus (Studi Perbandingan Antara Kampus Tembalang Universitas Diponegoro dan Kampus Tertre Universitas Nantes). Jurnal Pembangunan Wilayah dan Kota, 11(4), 484-497.

García-Feijoo, M., Eizaguirre, A., \& Rica-Aspiunza, A. (2020). Systematic review of sustainable-development-goal deployment in business schools. Sustainability, 12(1), 440.

Gatti, L., Ulrich, M., \& Seele, P. (2019). Education for sustainable development through business simulation games: An exploratory study of sustainability gamification and its effects on students' learning outcomes. Journal of cleaner production, 207, 667-678.

Gusviani, E. (2016). Analisis kemunculan sikap spiritual dan sikap sosial dalam kegiatan pembelajaran IPA kelas IV SD yang menggunakan KTSP dan kurikulum 2013. EduHumaniora| Jurnal Pendidikan Dasar Kampus Cibiru, 8(1), 96-106.

Indrati, D. A., \& Hariadi, P. P. (2016). Esd ( Education for Sustainable Development ) Melalui Pembelajaran Biologi. Symposium on Biology Education, 371-382.

Jones, P., Wynn, M., Hillier, D., \& Comfort, D. (2017). The Sustainable Development Goals and Information and Communication Technologies. Indonesian Journal of Sustainability Accounting and Management, 1(1), 1-15.

Julien, M. P., Chalmeau, R., Mainar, C. V., \& Léna, J. Y. (2018). An innovative framework for encouraging future thinking in ESD: A case study in a French school. Futures, 101, 26-35. 
Listiawati, N. (2013). Pelaksanaan Pendidikan untuk Pembangunan Berkelanjutan Oleh Beberapa Lembaga. Jurnal Pendidikan dan Kebudayaan, 19(3), 430-450.

Mensah, J. (2019). Sustainable development: Meaning, history, principles, pillars, and implications for human action: Literature review. Cogent Social Sciences, 5(1), 1653531.

Mochtar, N. E., Gasim, H., Hendarman, N. I., Wijiasih, A., Suryana, C., Restuningsih, K., \& Tartila, S. L. (2014). Pendidikan untuk Pembangunan Berkelanjutan (Education for Sustainable Development) di Indonesia. Komisi Nasional Indoneisa untuk UNESCO Kementrian Pendidikan dan Kebudayaan, (9).

Morton, S., Pencheon, D., \& Squires, N. (2017). Sustainable Development Goals (SDGs), and their implementation: A national global framework for health, development and equity needs a systems approach at every level. British Medical Bulletin, 124(1), 81-90.

OECD.(2008). OECD environmental outlook to 2030. Paris : OECD

Parker, L., \& Prabawa-Sear, K. (2019). Environmental Education in Indonesia: Creating Responsible Citizens in the Global South. Routledge.

Pedersen, C. S. (2018). The UN Sustainable Development Goals (SDGs) are a Great Gift to Business. Procedia CIRP, 68, 21-24.

Permatasari, P. (2016). UNPAR menuju Universitas yang Berkelanjutan (Sustainable University). Bandung: Fakultas Ekonomi Universitas Katolik Parahyangan.

Rosana, M. (2018). Kebijakan pembangunan berkelanjutan yang berwawasan lingkungan di Indonesia. Kelola: Jurnal Sosial Politik, 1(1), 148-163.

Seely, M., Ward, V., \& Wassenaar, T. (2014). Science education for sustainable development: the Gobabeb experience. Transactions of the Royal Society of South Africa, 69(3), 175178.

Sudjoko, S. (2014). Perkembangan dan konsep dasar pendidikan Lingkungan Hidup. Pendidikan lingkungan hidup, 1(1), 1-4.

Sudagung, A. D., Putri, V., Evan, J., Sasiva, I., \& Olifiani, L. P. (2019). Upaya Indonesia Mencapai Target Sustainable Development Goals Bidang Pendidikan di Kecamatan Sekayam Kabupaten Sanggau Kalimantan Barat (2014-2019). JURNAL POLINTER: KAJIAN POLITIK DAN HUBUNGAN INTERNASIONAL, 5(1), 1-27.

Sugiyono. (2011). Metode Penelitian Kuantatif Kualitatif Dan R\&D. Bandung: Alfabeta.

Sumiati, S. (2018). Peranan Guru Kelas Dalam Meningkatkan Motivasi Belajar Siswa. TARBAWI: Jurnal Pendidikan Agama Islam, 3(02), 145-164.

Surakusumah, W. (2009). Konsep pendidikan lingkungan di sekolah: model uji coba sekolah berwawasan lingkungan. Bandung: Universitas Pendidikan Indonesia.

Tristananda, P. W. (2018). MEMBUMIKAN EDUCATION FOR SUSTAINABLE DEVELOPMENT (ESD) DI INDONESIA DALAM MENGHADAPI ISU-ISU GLOBAL. Purwadita: Jurnal Agama dan Budaya, 2(2), 42-49.

Tosun, E. K., \& Gursakal, S. (2016). Environmental Literacy Levels of The Classroom Teachers In Turkey. The Online Journal of New Horizons In Education, 6(3), 33-59.

UNESC0. (2012). Education for Sustainable Development: Sourcebook. Paris : United Nations Educational, Scientific and Cultural Organization

Wardani, D. N. K. (2020). Analisis Implementasi Program Adiwiyata dalam Membangun Karakter Peduli Lingkungan. Southeast Asian Journal of Islamic Education Management, 1(1), 60-73. 